\title{
KAMPANYE LGBT DI MEDIA SOSIAL FACEBOOK DAN WHATSAPP
}

\author{
Reni Juliani \\ Program Studi Ilmu Komunikasi \\ Universitas Teuku Umar \\ Email: renijuliani@utu.ac.id
}

\begin{abstract}
Indonesia is a country where all religious leaders reject $L G B T$ behavior. Due to the uncertainty about the fate of their existence, LGBT people are increasingly aggressively advocating for legal protection and LGBT legalization in Indonesia. Internet campaigns are mostly chosen by LGBT people as a media campaign for them. This can be seen from the rise of social media used by the Indonesian people, especially Facebook and Whatsapp. Based on the phenomenom described above, the researcher is trying to figure out how the campaigns are being conducted by LGBT people on Facebook and Whatsapp. This study used a library research method where the results showed that Facebook and Whatsapp were indeed social media followers of the LGBT campaign. Facebook and Whatsapp have their own LGBT group. The Facebook and Whatsapp chat pages also include emo, stickers and gifs with LGBT symbols such as rainbow colors, pride, gay words and other words and illustrations that lead to LGBT.
\end{abstract}

Keywords: Campaign, LGBT, Facebook, Whatsapp.

\section{A. PENDAHULUAN}

Seiring perjalanan kehidupan manusia, peradaban manusia semakin lama semakin berkembang. Peradaban manusia yang dulunya hanya terbatas ruang dan waktu kini semakin maju dengan kehadiran teknologi. Kemajuan ilmu pengetahun dan teknologi mengubah tatanan kehidupan yang dulunya konvensional menjadi lebih modern. Sebagai contoh teknologi komunikasi yang semakin marak digunakan oleh masyarakat. Manusia bahkan berlomba-lomba memperbarui teknologi komunikasi yang mereka miliki. Sebagai contoh, manusia akan merasa tertantang untuk memiliki ponsel seri terbaru dengan kebaharuan inovasi yang ditawarkannya. Hal ini membuat Teknologi komunikasi dan informasi menjadi hal yang sangat penting saat ini. Ini merupakan bukti nyata akan kemajuan peradaban manusia itu sendiri.

Teknologi yang berdampak besar terhadap perkembangan peradaban manusia tidak hanya berdampak bagi kemajuan bagi manusia tapi juga kemunduran bagi moral, etika dan tingkah laku mereka. Sebagai contoh teknologi yang saat ini sering digunakan adalah ponsel. Melalui ponsel manusia mempelajari segala hal yang ditampilkan oleh media komunikasi tersebut. Peradaban dan perilaku yang menyimpang pun mulai menjamur. Dimana banyak kampanye-kampanye melalui media yang dimanfaatkan oleh pihak yang mempunyai kepentingan. Kampanye yang sangat hangat akhir-akhir ini berawal dari isu perjuangan Hak Asasi 
Manusia (HAM) yang bahkan maknanya kian membingungkan dan abu-abu. Hak Asasi Manusia (HAM) saat ini seakan menjadi celah bagi mereka yang merasa dianiaya dan dilanggar kebebasannya. HAM menjadi landasan mereka menyuarakan diri dan kelompoknya mengenai kebebasan. Hal inilah yang memicu perdebatan panjang yang terus berkembang dan tidak ada ujungnya. Seperti yang terjadi pada kaum LGBT (Lesbian, Gay, Biseksual dan Transgender) yang terus mencari pembelaan dan jaminan bagi mereka.

Isu mengenai LGBT sering menjadi topik utama dalam setiap diskusi dan penelitianpenelitian sosial. Perdebatan antara pihak satu dengan pihak lainnya masih terjadi sampai saat ini sehingga terlahirlah pihak pro dan pihak kontra terhadap LGBT. Apabila melihat pada sejarah masa lalu, LGBT bukanlah hal baru. Sejarah Nabi Luth sering sekali menjadi sumber referensi bagi peneliti. Nabi Luth yang hidup di tengah Kaum Sodom yang melakukan penyimpangan seks dan perilaku tidak bermoral sehingga diberikan azab yang sangat mengerikan oleh Allah SWT.

Dalam kitab perjanjian lama juga mengisahkan mengenai sejarah masa lalu kaum LGBT dan azab yang diberikan Tuhan kepada kaum tersebut. Dalam kitab tersebut dikisahkan ada sebuah kota bernama Sodom yang terletak di antara Israel dan Yordania. Kota Sodom terbentang memanjang di antara kedua negara tersebut. Suatu ketika terjadilah gempa vulkanik dengan diiringi letusan larva yang membumihanguskan kota tersebut. (Saleh dan Arif, 2017:154).

Di dalam Al-Qur' an telah secara tegas melarang perilaku LGBT. Larangan tentang LGBT tidak hanya datang dari Islam. Seluruh pemuka agama di Indonesia telah sepakat untuk menentang LGBT. Dalam ajaran Kristen, hubungan badan antara lelaki dan perempuan dianggap manusiawi, namun beda halnya dengan homoseksual atau gay yang melakukan hubungan badan dengan sejenisnya. Dalam Al Kitab pun tertulis “Alkitab mengatakan dengan jelas bahwa Allah merancang agar hubungan seks dilakukan hanya di antara pria dan wanita, dan hanya dalam ikatan perkawinan" (Kejadian 1:27, 28; Imamat 18:22; Amsal 5:18, 19). Alkitab mengutuk percabulan, yang mencakup perilaku homoseksual maupun heteroseksual terlarang. Hubungan ini dipandang oleh ajaran moral gerejawi berlawanan dengan nilai-nilai pokok dalam seksualitas. Akan tetapi masih terdapat perdebatan mengenai hal ini di gereja, mereka memperdebatkan apakah homoseksual patut dikatakan sebagai penyimpangan ataupun sebagai kelainan yang seharusnya ditolong, baik pertolongan seperti pertolongan medis, karena dianggap sebagai penyakit yang harus diobati, ataupun dalam bentuk pengertian dan dukungan hidup (Saleh dan Arif, 2017:154).

Tidak berbeda dengan agama Kristen yang tidak menyetujui perilaku LGBT, dalam pandangan Hindu, perilaku tersebut juga dianggap sebuah penyimpangan. Kama ataupun kenikmatan sensual yang merupakan istilah tersendiri dalam agama Hindu, merupakan salah satu tujuan hidup puruhartahas (darma, arta, kama, dan moksa) dan seks merupakan hal yang baik yang harus dilakukan dalam sebuah pernikahan yang sah. Agama Hindu yang percaya dengan 
sistem reinkarnasi ini mempunyai pandangan bahwa penyimpangan seks LGBT merupakan hal yang tidak diperbolehkan. Walaupun tidak dibahas secara rinci akan tetapi agama ini hanya membahas tentang karma yang ia dapatkan karna hal tersebut merupakan hal yang meyimpang dari nilai norma. (Saleh dan Arif, 2017:154).

Dalam agama Hindu, seseorang yang melakukan hubungan badan dengan sesama jenisnya atau melakukan hubungan yang dianggap sebuah penyimpangan dan bukan kewajaran akan dikeluarkan dari Sangha yaitu persatuan para biksu. Seorang biksu sudah seharusnya menahan dirinya dari segala hal yang bersifat duniawi dan apabila seseorang melanggar hal tersebut maka seseorang tersebut akan dikeluarkan. Walaupun di negara-negara yang banyak penganut agama Buddha, tidak ada pelarangan khusus secara nyata berdasarkan hukum yang berlaku mengenai LGBT, bukanlah berarti LGBT di negara-negara tersebut diterima dengan tangan terbuka. Hal ini dikarenakan pengaruh agama Buddha penuh dengan toleransi dan mengedepankan kemanusiaan. Walaupun demikian, diskriminasi terhadap kaum LGBT sering terjadi di negara-negara tersebut. Yang patut digarisbawahi disini adalah tidak ada bagian dalam agama Buddha yang membenarkan adanya kutukan, hukuman, maupun penolakan terhadap kaum LGBT (Saleh dan Arif, 2017:155).

Ketidakpastian nasib keberadaan kaum LGBT membuat mereka semakin gencar dalam mengampanyekan diri mereka. Hal ini memiliki tujuan salah satunya untuk pelegalan LGBT di Indonesia. Kampenye di internet banyak dipilih oleh kaum LGBT. Hal ini melihat bagaimana maraknya media sosial digunakan oleh masyarakat Indonesia, khususnya media Facebook dan Whatsapp. Berangkat dari fenomena yang telah dipaparkan di atas, maka penelitian akan mencoba mengupas mengenai bagaimana kampanye yang dilakukan kaum LGBT di media sosial Facebook dan Whatsapp.

\section{B. TINJAUAN PUSTAKA}

\section{Media Sosial}

Perkembangan teknologi informasi semakin lama semakin berkembang. Teknologi ini membawa kemudahan informasi dan komunikasi bagi penggunanya. Sarana komunikasi yang sedang populer saat ini adalah media sosial. Media sosial merupakan media yang mampu menghubungkan seseorang dengan orang lain, seseorang dapat terhubung dengan orang dari segala penjuru. Berbagi informasi dapat ditranformasikan melalui dunia maya ini. Kapan dan dimana saja, seorang bisa mendapatkan berbagai macam informasi dari berbagai pihak. Demikian juga, seseorang dapat membagikan informasi kepada orang lain dengan menggunakan media sosial secara instan dan cepat. Media sosial bisa digolongkan ke dalam media massa, karena memiliki sifat yang terbuka untuk semua khalayak yang dapat mengaksesnya. Media sosial juga 
bersifat tanpa batasan, baik batas geografis bahkan sampai kepada batasan ideologis. Media sosial juga mampu masuk ke ranah pribadi khalayak. Mayoritas rakyat Indonesia, tidak hanya ada di kawasan perkotaan, melainkan juga di daerah pedesaan, tidak mau ketinggalan dalam mengakses media sosial. Diantara media sosial yang paling sering diunduh adalah facebook, whatsapp, twitter, path, youtube, instagram, kaskus, LINE, my space, dan blackberry messenger (Siagian, 2015:23).

Kaplan dan Haenlein (Kapriani dan Lubis, 2014:161) menjelaskan bahwa media sosial dapat dikelompokkan menjadi beberapa bagian besar dan diantaranya:

1. Social Networks, media sosial untuk bersosialisasi dan berinteraksi (contohnya: Facebook, myspace, hi5, Linked in, bebo)

2. Discuss, media sosial yang memfasilitasi sekelompok orang untuk melakukan obrolan dan diskusi (contohnya :google talk, yahoo! M, skype, phorum)

3. Share, media sosial yang memfasilitasi kita untuk saling berbagi diantaranya file, video, music (youtube, slideshare, feedback, flickr, crowdstorm)

4. Publish, (wordpredss, wikipedia, blog, wikia, digg)

5. Micro blog media sosial yang untuk berinteraksi dan bersosialisasi akan tetapi ada batasan terhadap jumlah huruf yang ditulis (twitter, plurk, pownce, twirxr, plazes, tweetpeek).

Pertiwi (2018) juga menjelaskan bahwa pengguna Facebook didominasi generasi muda yang berumur 18-24 tahun. Kebijakan Facebook dan Whatsapp yang mendeklarasikan perusahaannya untuk mendukung kampanye kaum LGBT ini akan sangat membahayakan generasi muda yang menjadi pengguna media sosial terbanyak di Indonesia. LGBT di media sosial mempengaruhi bagaimana gaya hidup yang bebas seperti yang cenderung dilakukan oleh kaum modern. Semakin lama, kampanye ini akan mempengaruhi pandangan mereka tentang LGBT dan membuat LGBT tidak lagi dipandang sebagai kaum yang menyimpang dari adat, norma, agama dan hukum di Indonesia. "Negara kita ini adalah negara yang berdasarkan Pancasila. Yang mana di sila pertama ialah Ketuhanan yang Maha Esa. Artinya jangan sampai segala apa yang kita lakukan bersimpangan dengan sila ketuhanan. Bahwa tidak ada agama apapun yang bisa menerima hubungan sesama jenis itu termasuk agama muslim," kata Ketua Majelis Ulama Indonesia (MUI) Jambi Hadri Hasan kepada detikcom.

Menurut Darwin (Kapriani dan Lubis, 2014:162) berdasarkan hasil lembaga riset MarkPlus Insight. Jumlah pengguna internet di Indonesia tumbuh signifikan hingga 22\% dari 62 juta di tahun 2012 menjadi 74,57 juta di tahun 2013. Angka pengguna internet di Indonesia akan menembus 100 juta jiwa di tahun 2015 nanti. Netizen atau pengguna internet yang sehari-harinya 
menghabiskan waktu lebih dari tiga jam dalam dunia maya meningkat dari 24,2 juta di tahun 2012 menjadi 31,7 juta orang di tahun 2013. Hampir separuh dari Netizen Indonesia merupakan pengguna internet muda dibawah 30 tahun, sedangkan 16\% adalah para Netizen berusia diatas 45 tahun. Bahkan hampir 95\% Netizen tersebut adalah pengguna internet melalui perangkat mobile (smartphone). Pada survei terlihat bahwa Netizen menghabiskan uangnya sekitar Rp.50 000Rp100 000 untuk internet per-bulan, bahkan terdapat 16,8\% Netizen yang rela mengeluarkan kocek di atas Rp150 000 per-bulan untuk keperluan internet.

\section{Facebook}

Mark Zuckerberg merupakan pendiri Facebook. Dia merupakan lulusan Universitas Hardvard dan mantan murid Ardsley High school. Facebook pertama kali diluncurkan pada 4 Februari 2004 dan sifatnya terbatas. Awalnya Facebook hanya bisa diakses untuk peserta didik Harvard College. Selama dua bulan berikutnya, anggota pengikut Facebook semakin meningkat, dan aksesnya diperluas ke sekolah lain di wilayah Boston (Boston College, Boston University, MIT, Tuft), Rocherster, Stanford, NYU, Northwestern, dan semua sekolah yang termasuk dalam ivy League. Melihat perkembangan Facebook yang semakin pesat, Mark Zuckerberg mulai mengembangkan pula jaringan untuk sekolah tingkat atas dan beberapa perusahaan besar. Tercatat dalam sejarah pada tanggal 11 september 2006, setiap orang yang memiliki alamat email dapat menjadi pengikut facebook dan memiliki akun mereka sendiri. Bahkan pemilik akun bisa menyesuaikan diri mereka dalam memilih grup mana saja yang ada di dalam Facebook. Mereka dapat memilih untuk bergabung dengan satu atau lebih jaringan yang tersedia, seperti berdasarkan sekolah mereka, pekerjaan bahkan berdasarkan tempat tinggal mereka. Namun, dalam belakangan ini, Facebook menemui berbagai masalah salah satunya pemblokiran pada negara Suriah, Iran dan beberapa tempat kerja agar para pekerja tidak melakukan penyalahgunaan waktu kerjanya untuk mengakses Facebook. Sehingga Facebook menjadi penyebab mereka lalai dalam pekerjaan mereka. Selain itu, Zuckerberg juga mempunyai masalah lainnya yaitu tentang tuduhan bahwa dia telah mencuri kode progam dari teman-temannya untuk membuat facebook. Sejak dibuka untuk umum pada 2006, Facebook telah menjelajah dunia dan menjadi situs nomor satu di beberapa negara. Iran, yang sebelumnya pernah memblokir Facebook demi menangkal pengaruh Yahudi, akhirnya tidak dapat menahan canggihnya teknologi ini. Menurut situs pemeringkat web, alexa, Facebook bahkan menjadi situs nomor satu di Iran. Begitu juga di Eropa, Spanyol, Inggris, Turki, Prancis dan Jerman menyebut facebook sebagai situs media sosial nomor satu di Negara masing-masing. (Rofi'i, 2017:599-600).

Seperti halnya yang terjadi di negara-negara lainnya, facebook di Indonesia juga sangat disambut baik oleh masyarakat dan hal ini menjadikan facebook sebagai media sosial utama yang di akses di Indonesia. Indonesia bahkan menduduki peringkat ke-4 di dunia dengan setelah 
Amerika, India dan Brazil sebagai pengguna Facebook paling aktif. Hal ini diungkap dari laporan riset We Are Social dan Hootsuite yang dirilis di LinkedIn dimana Facebook diklaim kian mendominasi jagat media sosial di dunia (Jeko, 2017).

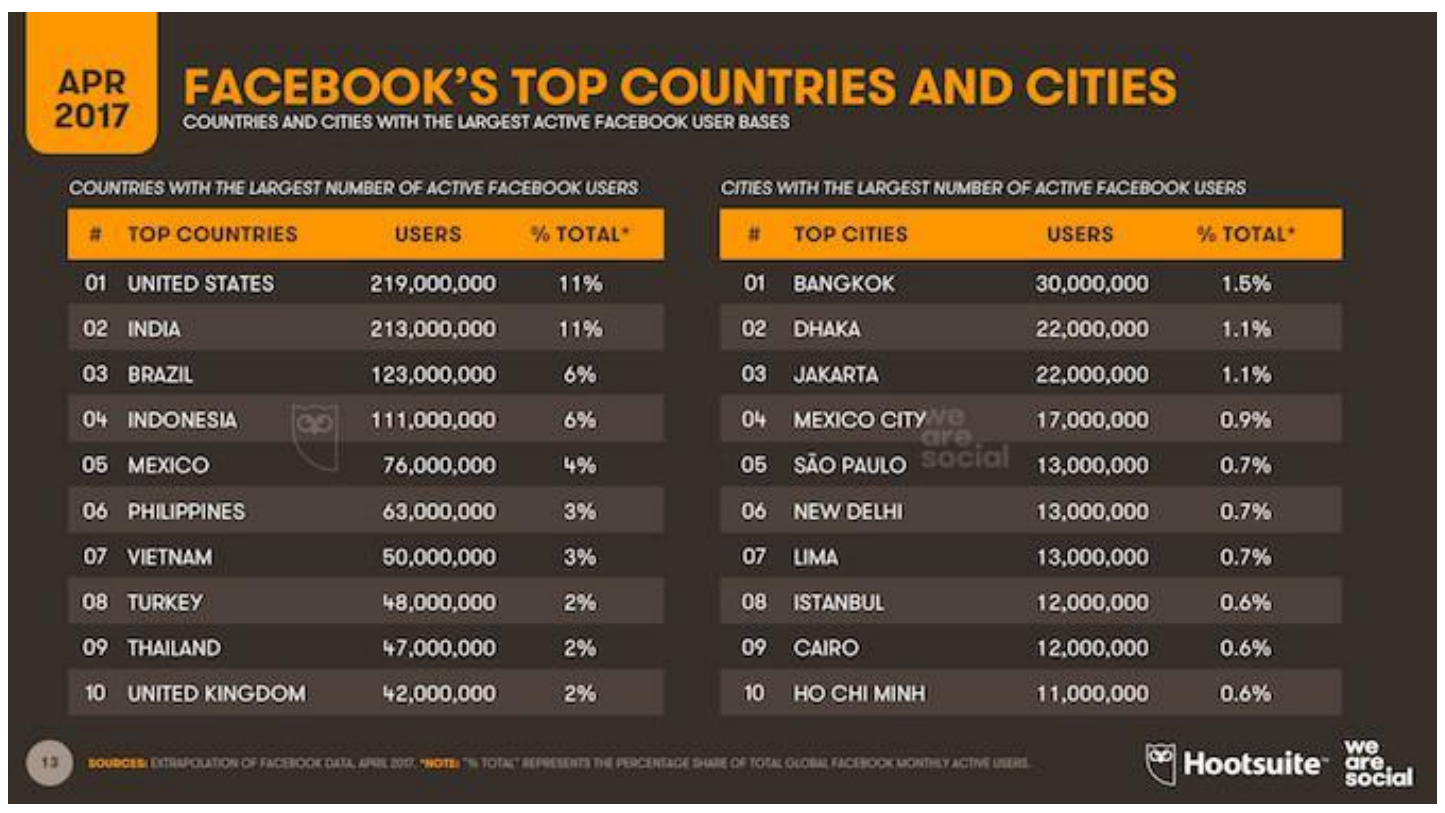

Sumber: Jeko (2017)

Seperti yang terlihat pada gambar di atas, Indonesia berhasil menjadi peringkat ke-4 sebagai pengguna Facebook terbesar dunia, menurut data yang pernah dirilis oleh Internet World Stats di akhir tahun 2012 lalu. Data dari Webershandwick menunjukkan bahwa pengguna Facebook di Indonesia mencapai angka 65 juta pengguna aktif, 33 juta pengguna aktif per harinya, 55 juta pengguna aktif yang memakai perangkat mobile dalam pengaksesannya per bulan dan sekitar 28 juta pengguna aktif yang memakai perangkat mobile per harinya (Ardha, 2014:115). Data tersebut menunjukkan bahwa pengguna Facebook tidak hanya menggunakan komputer namun juga menggunakan perangkat mobile mereka untuk mengakses Facebook.

Aktivitas Facebook didasarkan semata-mata pada penggunanya. Facebook tidak hanya sebatas mengakses informasi namun penggunanya juga dapat membentuk jaringan-jaringan baru mereka. Pengguna Facebook dapat mengirimkan informasi dalam bentuk teks, gambar atau pun keduanya. Mereka juga dapat menerima tanggapan dari pengguna lain dalam bentuk "Like" tombol, dan bahkan mereka bisa saling berbalas komentar. Mereka juga dapat meneruskan posting ke kontak Facebook mereka sendiri "contact using", "Share" pilihan. Salah satu fitur populer Facebook adalah halaman komunitas untuk kepentingan bersama. Banyak kelompok membuat sebuah halaman untuk kelompok mereka sendiri, dan ketika pengguna mengklik tombol "Like " tombol, pengguna yang menunjukkan bahwa mereka ingin menerima update setiap kali 
kelompok tersebut meng-update informasi baru ke Facebook (Ardha, 2014:110). Halaman komunitas inilah yang sering dimanfaatkan kaum LGBT dalam mengkampanyekan diri mereka ke publik melalui Facebook. Mereka membuat grup dan menyebarkan informasi-informasi mengenai kelompok mereka. Selain itu Facebook juga terkenal dengan media sosial yang pro LGBT. Hal ini tercermin saat Facebook merayakan hari LGBT sedunia dengan memasang tema pelangi dan pride.

\section{Whatsapp}

Whatsapp merupakan salah satu media sosial yang sangat populer saat ini. Whatsapp banyak digunakan untuk menyampaikan informasi kepada orang lain baik kepada individu maupun kelompok. Whatsapp juga digunakan untuk membangun jaringan. Media sosial ini sering dimanfaatkan untuk kepentingan bersosialisasi bagi penggunanya. Melakukan percakapan melalui menu chat, pengguna dapat mengirimkan pesan kepada orang lain. mereka juga bisa meng-copy, men-delete, atau mem-forward pesan. Whatsapp juga dapat mengirim gambar, file bahkan dapat mengirimkan pesan suara maupun share lokasi keberadaan pengguna. Media sosial ini menyediakan fitur grup chat, dimana pengguna bisa mengumpulkan beberapa kontak untuk membuat sebuah grup chat (Trisnani, 2017:2).

Salah satu manfaat positif yang didapatkan bagi pengguna Whatsapp yaitu mempermudah penggunanya untuk berkomunikasi. WhatsApp adalah media komunikasi, baik digunakan dalam jarak dekat maupun jarak jauh. Media ini juga sebagai alat komunikasi lisan atau tulisan bahkan mereka dapat menggunakan fitur video call untuk berinteraksi dengan orang lain. Selain itu media ini dianggap sangat praktis karena dengan hanya menginstall aplikasi Whatsapp di smarthphone, penggunanya dapat mengakses Whatsapp dimana saja asalkan terhubung dengan internet. Oleh sebab itu maka media sosial ini sangat berguna untuk alat komunikasi jarak jauh yang semakin efektif dan efisien. Manfaat media sosial lainnya sebagai alat penghilang stress dan hiburan. Seperti yang telah diungkapkan sebelumnya bahwa media sosial WhatsApp saat ini sudah memiliki feature yang sangat lengkap, sehingga feature tersebut dapat dijadikan seseorang untuk menghilangkan stress. (Suryadi, Ginanjar dan Priyatna, 2018:7). 


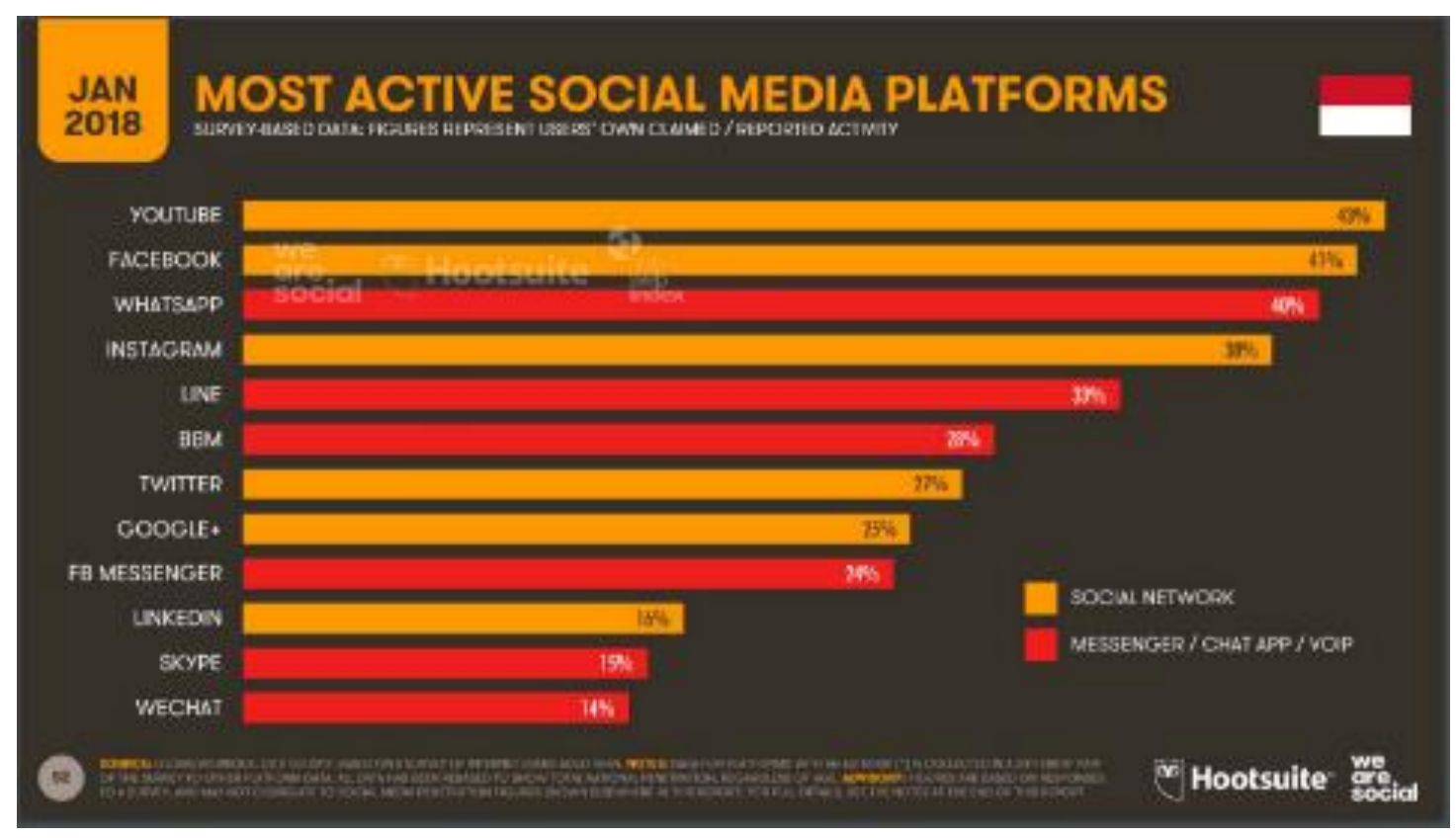

Sumber: Anggraeni, 2018

Dari data di atas, We Are Social menyebutkan bahwa YouTube menjadi The winner dalam penggunaan media sosial teraktif yang diakses oleh pengguna internet di Indonesia. Angka pengguna terbanyak kedua adalah media sosial Facebook, setelah itu disusul WhatsApp di posisi ketiga, Instagram di posisi keempat dan Line di posisi kelima. Pada daftar aplikasi terbanyak diunduh sepanjang tahun 2017, WhatsApp Messenger yang menjadi juara sehingga dinobatkan sebagai pilihan favorit pengguna internet di Indonesia. Namun dapat dilihat dari data di atas bahwa popularitas aplikasi Facebook di Indonesia belum meredup, dibuktikan oleh kehadirannya di posisi kedua daftar tersebut, dan diikuti media sosial lain yang juga dinaungi Facebook, yaitu Instagram di posisi ketiga (Anggraeni, 2018).

\section{LGBT}

LGBT merupakan singkatan dari "lesbian, gay, biseksual, transgender" istilah ini mulai digunakan pada tahun 1990-an menggantikan frasa "komunitas gay" karena istilah ini lebih mewakili kelompok-kelompok yang telah disebutkan di atas. Istilah LGBT ini mulai menjamur di segala penjuru dan media hal ini bertujuan untuk penunjukan diri mereka dan untuk mendapatkan pengakuan dari berbagai pihak. Istilah ini juga diterapkan oleh mayoritas komunitas dan media yang berbasis identitas seksualitas dan gender di Amerika Serikat dan beberapa negara berbahasa inggris lainnya. Namun masih banyak pro dan kontra terkai dengan akronim penyebutan kelompok ini. Beberapa orang dalam kelompok yang disebutkan merasa tidak berhubungan dengan kelompok lain dan tidak menyukai penyeragaman ini. Beberapa dari mereka lainnya berpendapat bahwa pergerakan transgender dan transeksual sangat berbeda dengan pergerakan kaum LGBT. Homoseksual merupakan istilah pertama yang banyak digunakan yang 
dianggap mengandung konotasi negatif dan cenderung digantikan oleh "homofil" pada era 1950an dan 1960-an dan kemudian gay dan lesbian pada tahun 1970-an frase "gay dan lesbian" menjadi lebih umum setelah identitas kaum lesbian semakin terbentuk selanjutnya, setelah adanya penyebutan identitas kaum lesbian, kaum lainnya seperti kaum biseksual dan transgender juga menuntut pengakuan dalam komunitas yang lebih besar. Setelah euforia kerusuhan stomewall mereda beberapa gay dan lesbian menjadi kurang menerima kaum biseksual dan transgender. Terjadi kerusuhan ini menandakan istilah LGBT itu sendiri dibentuk melalui sejarah panjang dan perdebatan-perdebatan berujung keributan antar sesama mereka. Selain itu mayoritas masyarakat juga tidak senang dengan kehadiran kelompok ini atau perkumpulan para LGBT dikarenakan dianggap sebagai kemunduran dan malapetakan bagi perkembangan zaman terutama generasi muda yang sedang pada fase tumbuh gairah seksualnya. Bukan hanya dampak terhadap anak tapi kaum LGBT ini juga menjadi ancaman bagi kesehatan masyarakat pada umumnya, mereka dianggap sebagai wabah yang bisa menjangkit siapa saja dan dalam kondisi legalitas Kaum lesbian, gay, biseksual, dan trangender (LGBT) di Indonesia akan menghadapi tantangan hukum dan perasangka yang tidak dialami oleh penduduk non-LGBT. (Suherry, 2016: 91).

\section{Kampanye LGBT di Facebook dan Whatsapp}

Kampanye menurut Kotler dan Roberto (dalam Cangara, 2009: 284) "Campaign is an organized effort conducted by one group (the change agent) which intends to persuade other (the target adopters), to accept, modify or abandon certain ideas, attitudes, practise and behavior." Kampanye merupakan sebuah usaha yang diorganisasikan oleh satu kelompok (agen perubahan) yang bertujuan untuk mempengaruhi target sasaran agar dapat menerima, memodifikasi atau meninggalkan ide, sikap dan perilaku tertentu.

Beda halnya dengan kampanye yang dilakukan suatu kelompok di dunia nyata, Sifat kampanye di media sosial bisa merupakan kebalikannya. Jika di dunia nyata kampanye terkesan berisik, bersuara keras tapi tanpa bukti nyata, di media sosial adalah antitesis dari berisik dan bising tersebut, yaitu bermakna. Setiap suara punya arti, memiliki pembuktiannya sendiri-sendiri. (Ardha, 2014:117).

\section{Kampanye LGBT Melalui Grup LGBT di Facebook dan Whatsapp}

Pada situs chapchapmarket.co.ke (Steve, 2018) terdapat banyak sekali link-link grup LGBT di Whatsapp. Ada lebih dari puluhan grup tersedia di situs tersebut. Hal ini menandakan bahwa media sosial Whatsapp digunakan sebagai media sosialisasi kaum LGBT serta ajang kampanye mereka kepada sesama mereka dan kepada pengguna Whatsapp lainnya. Hal ini dikarenakan untuk menjadi anggota dari grup tersebut, pengguna dengan mudah bisa masuk. 
Hanya dengan mengakses link yang dimaksud dan pengguna bisa masuk ke dalam grup dan dapat berkomunikasi dengan pengguna lainnya di dalam grup tersebut.

Baru-baru ini, ratusan siswa-siswi di Garut, Jawa Barat menggelar demonstrasi massa menolak grup LGBT yang ada di Facebook yang keanggotaannya adalah remaja. Mereka khawatir kelompok "gay" pelajar di grup media sosial Facebook itu dapat menghancurkan moral generasi muda bangsa. Seperti diketahui, grup gay tersebut memiliki jumlah anggota lebih dari 2.600 orang yang terdiri dari para pelajar SMP dan SMA. Grup ini muncul di Facebook dengan nama 'Kumpulan Barudak Gay SMP/SMA Garut'. Beberapa postingan yang muncul menandakan grup tersebut masih aktif. Screenshoot laman grup tersebut telah menyebar melalui aplikasi pesan singkat WhatsApp, sehingga menimbulkan keresahan berbagai kalangan. Keberadaan grup penyuka sesama jenis itu juga bermunculan di grup WhatsApp lainnya. "Biasanya mereka yang jadi penyuka sesama jenis ini karena faktor lingkungan. Ditambah kurangnya kasih sayang dari keluarga," tuturnya. Ketua Garut Education Watch (GEW), Sony Mulyadi Supriadi, menyampaikan hal yang sama. Ia menilai fenomena ini harus mendapat perhatian yang sangat serius dari semua kalangan. "Bukan berarti menjadi tanggung jawab pihak sekolah dan dinas pendidikan saja. Ini merupakan tanggung jawab bersama dan semua elemen harus turun tangan untuk mengatasinya," kata Sony (Ferdiansyah, 2018).

\section{Kampanye LGBT Melalui Emo, Stiker dan Gif di Facebook dan Whatsapp}

Pelangi sering diidentikkan dengan simbol LGBT. Simbol pelangi yang mewakilkan kaum LGBT ini bermakna dan bersejarah. Pada awalnya, simbol pelangi ini merupakan urutan warna yang terdiri dari warna pink atau merah muda yang mempunyai arti seksualitas, kemudian dilanjutkan dengan warna merah yang berarti kehidupan, lalu warna orange berarti penyembuhan, warna kuning melambangkan matahari, hijau merujuk pada alam yang hijau, toska merupakan simbol dari seni, biru berarti perdamaian dan ungu memiliki arti semangat. Simbol pelangi ini pertama kali dicetuskan oleh Gilbert Baker pada tahun 1978. Baker merupakan seorang aktivis gay, seniman, sekaligus tentara veteran asal Amerika Serikat. Simbol pelangi ini dikatakan merupakan inspirasi dari lagu berjudul Somewhere Over the Rainbow yang diciptakan oleh Judy Garland. Seiring berjalannya waktu, warna ini kemudian dibuat lebih padat yang dulunya berjumlah 8 warna sekarang dilambangkan dengan hanya menggunakan 6 warna saja yakni merah, orange, kuning, hijau, biru, dan ungu. Bendera ini pertama kali digunakan sebagai identitas oleh kaum gay pada 25 Juni 1978 yang merupakan parade hari kebebasan kaum gay ( gay freedom day parade) di San Francisco, Amerika (Grovier, 2016). 


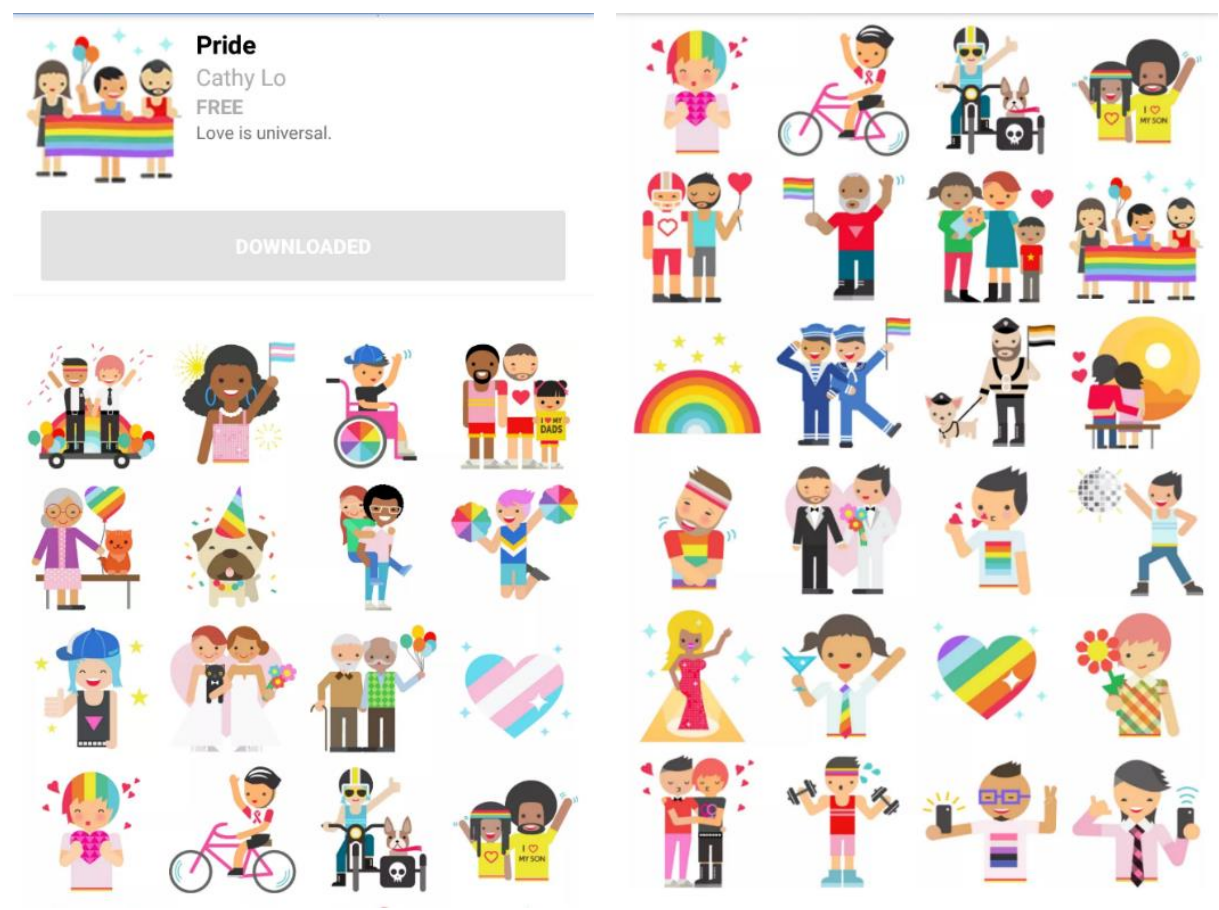

Sumber: Facebook

Selain pada stiker Pride yang menampilkan berbagai ilustrasi terkait LGBT, gambar bergerak atau gift bertemakan pelangi juga dapat ditemukan di laman Facebook. Gambar-gambar bertuliskan Love Wins dengan menggunakan warna-warna pelangi sebagai simbol kaum LGBT menjadi kampanye mereka melalui media sosial ini. Dukungan media seperti ini menjadikan kaum LGBT semakin gencar melakukan kampanye dan propaganda untuk mendapatkan dukungan dan untuk memperkuat kaum mereka. 


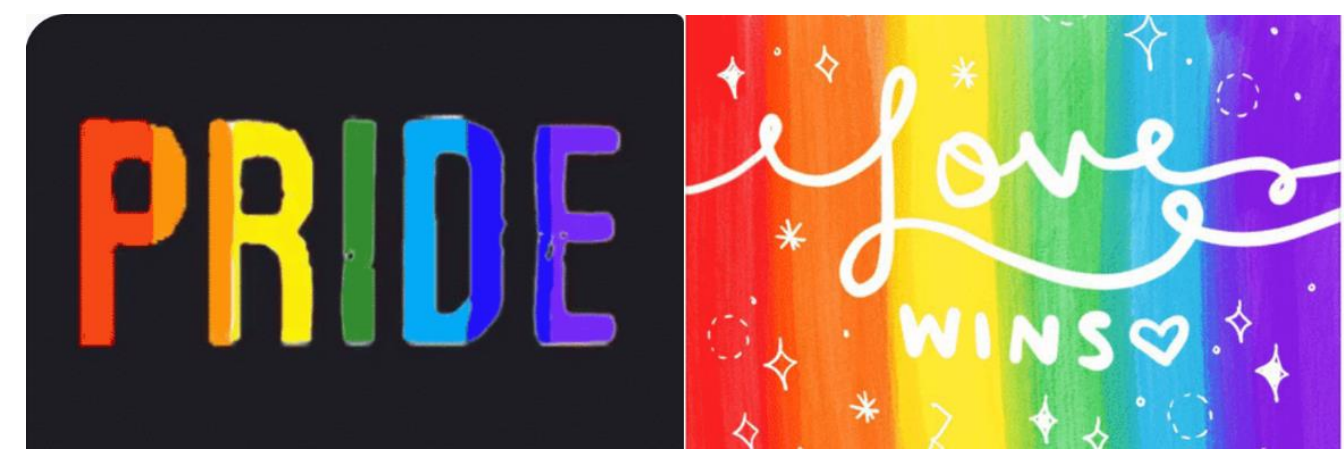

Sumber: Facebook

Kata Love Wins ini dapat dimakna bahwa tidak ada yang dapat menandingi sebuah cinta. cinta akan selalu menang dalam kondisi apapun dan pemberian gif tersebut akan diterima oleh semua kalangan ikut serta dan andil dalam kampanye pelegalan LGBT di seluruh belahan dunia termasuk juga di Indonesia dikarenakan emo, stiker dan gif tersebut tidak mendapat pencekalan dari pemerintah.

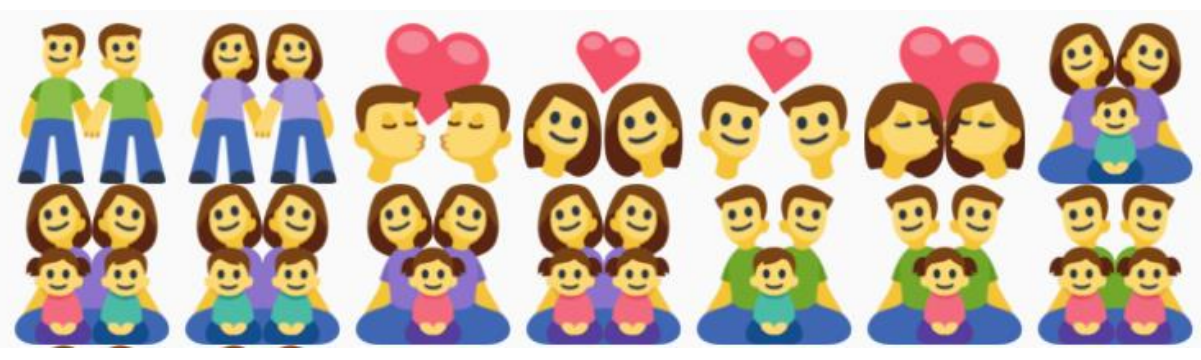

Sumber: Facebook 


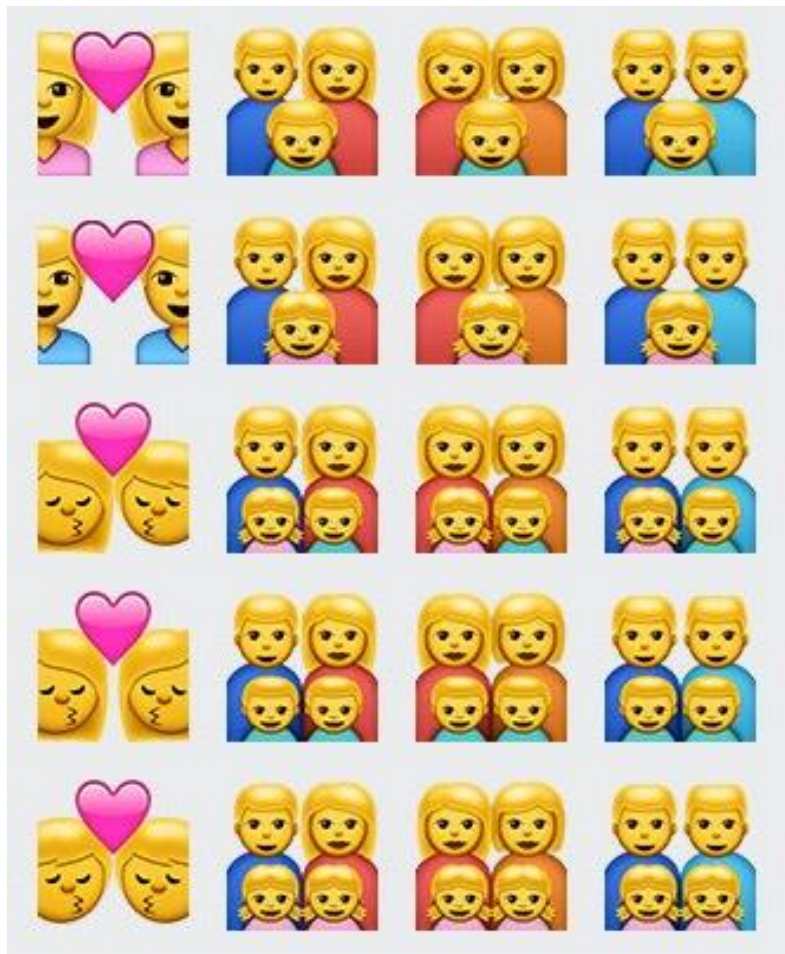

Sumber: Whatsapp

Selain emo, stiker dan gif yang menjurus kepada Pro LGBT, adapula ilustrasi dalam emotikon yang juga menjurus pada LGBT. Seperti adegan yang dilakukan oleh pasangan sesama jenis seperti adegan bergandengan tangan, berciuman, dan berkeluarga. Dalam gambar tersebut ditampilkan ilustrasi hubungan keluarga berjenis kelamin sama (LGBT) yang harmonis. Keharmonisan dan kebahagiaan tersebut digambarkan sama seperti kebahagiaan pasangan berjenis kelamin berbeda. Hal ini merujuk pada lekukan senyuman tampak utuh yang mengisyaratkan kebahagiaan atau suasana hati ceria dari emotikon pro LGBT tersebut.

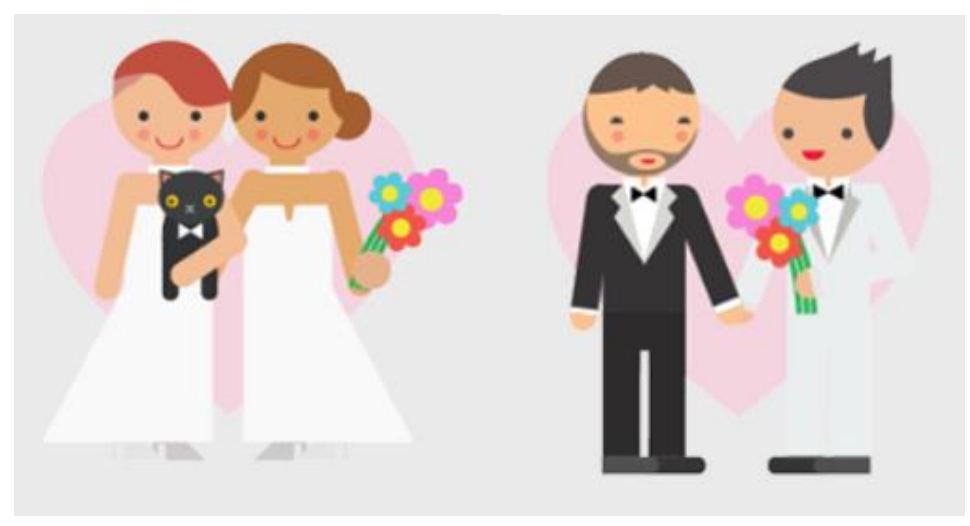

Sumber: Facebook 


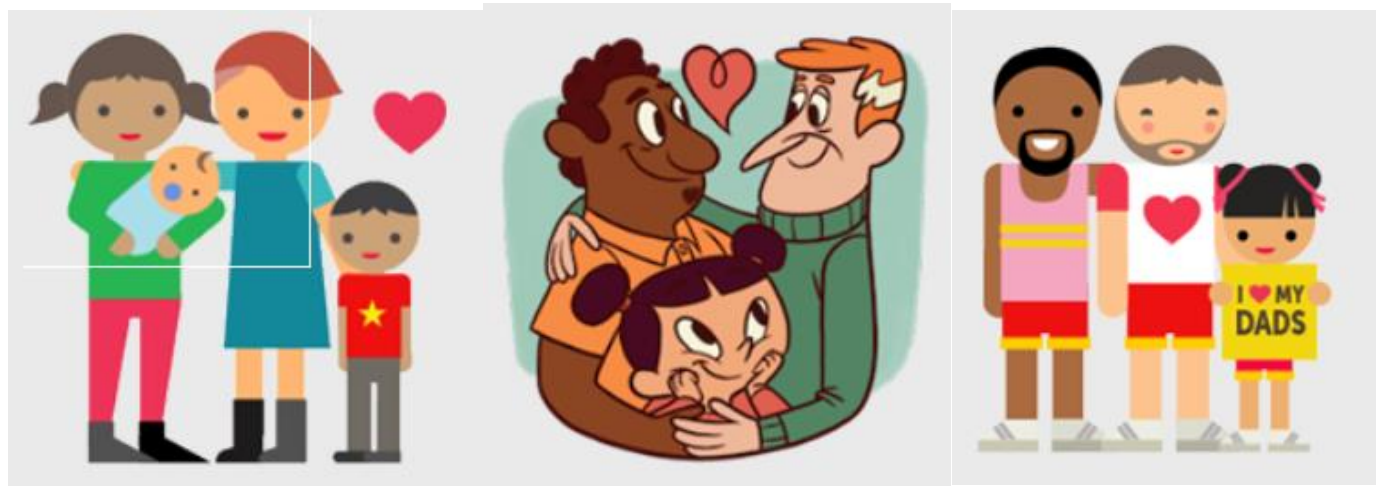

Sumber: Facebook

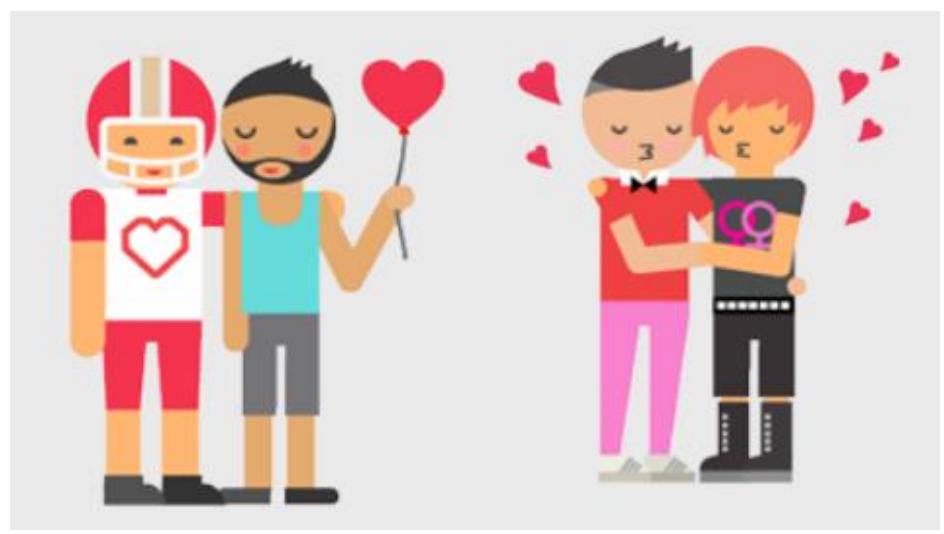

Sumber: Facebook

Pembentukan grup LGBT dan Emo, stiker, gif dan ilustrasi pro LGBT yang terdapat pada media sosial Facebook dan Whatsapp menegaskan kalau kedua media sosial tersohor di Indonesia ini merupakan media kampanye LGBT yang bahkan mendukung kampanye-kampanye mereka. Dengan sangat mudah kita bisa menemukan banyak sekali ilustrasi gambar yang menjurus ke LGBT. Dan sampai saat ini ilustrasi tersebut masih bisa diakses oleh siapapun pengguna kedua media sosial ini. Bahkan di Indonesia sekalipun yang merupakan negara yang taat beragama bahkan kelima pemuka agamanya sepakat menentang perilaku LGBT, namun kampanyekampanye LGBT masih dengan mudah tersebat di media Facebook dan Whatsapp. 


\section{PENUTUP}

Media sosial Facebook dan Whatsapp merupakan media yang pro dalam kampanyekampanye LGBT. Hal ini dibuktikan dengan banyaknya tersebar simbol-simbol yang tersebar yang melambangkan LGBT. Simbol-simbol tersebut berupa warna pelangi, kata-kata pride, gay dan kata-kata yang menjurus LGBT serta ilustrasi yang menggambarkan LGBT. Selain itu Facebook dan Whatsapp merupakan media propaganda kaum LGBT dalam kampanye mereka. Di media ini tidak sedikit didapati grup-grup yang dibuat oleh kaum LGBT sebagai wadah mereka mengkampanyekan diri mereka ke khalayak.

\section{REFERENSI}

\section{Buku}

Cangara, Hafied (2009). Komunikasi Politik: Konsep, Teori, dan Strategi. Jakarta, PT. Raja Grafindo Persada.

\section{Jurnal dan Penelitian Lainnya}

Ardha, Berliani. 2014. Social Media Sebagai Media Kampanye Partai Politik 2014 Di Indonesia. Jurnal Visi Komunikasi, Volume XIII (01): 105-120.

Kapriani, Dea Rizki dan Lubis, Djuana P. 2014. Efektivitas Media Sosial untuk Gerakan Sosial Pelestarian Lingkungan. Sodality : Jurnal Sosiologi Pedesaan, Vol II (3): 160-170.

Rofi'i, Fathur. 2017. Dampak Negatif Facebook Terhadap Pendidikan Aqidah Akhlak. Sumbula, Vol II (2): 589-611.

Saleh, Gunawan dan Arif, Muhammad. 2017. Rekayasa Sosial Dalam Fenomena Save LGBT. Jurnal Komunikasi Global, Volume XI (2): 148-163.

Siagian, Haidir Fitra. 2015. Pengaruh Dan Efektivitas Penggunaan Media Sosial Sebagai Bentuk Saluran Komunikasi. Jurnal Al-Khitabah, Vol. II (1): 17 - 26.

Suherry, Edward Mandala. 2016. Lesbian, Gay, Biseksual dan Transgender (LGBT) dalam Perspektif Masyarakat dan Agama. Jurnal Aristo, Vol IV (2): 89-99. 
Suryadi, Edi, Ginanjar, M Hidayat dan Priyatna, M. 2018. Penggunaan Sosial Media Whatsapp Dan Pengaruhnya Terhadap Disiplin Belajar Peserta Didik Pada Mata Pelajaran Pendidikan Agama Islam. Edukasi Islam, Jurnal Pendidikan Islam Vol VII (1):1-22.

Trisnani. 2017. Pemanfaatan Whatsapp Sebagai Media Komunikasi Dan Kepuasan Dalam Penyampaian Pesan Dikalangan Tokoh Masyarakat. Jurnal Komunikasi. Media Dan Informatika Vol VI (3): 1-12.

\section{Internet}

Anggraeni, Lufthi. 2018. 130 Juta Penduduk Indonesia Sudah Pakai Medsos. http://teknologi.metrotvnews.com/news-teknologi/0k8L1edk-130-juta-pendudukindonesia-sudah-pakai-medsos. Diakses pada tanggal 04 November 2018.

Ferdiansyah, Fani. 2018. Resah Ada Grup Gay di Garut, Ratusan Pelajar di Garut Gelar Deklarasi. http://www.pikiran-rakyat.com/jawa-barat/2018/10/13/resah-ada-grup-gay-difacebook-ratusan-pelajar-garut-gelar-deklarasi-431521. Diakses pada tanggal 04 November 2018.

Grovier, Kelly. 2016. Mengapa Simbol Kaum Gay Bergambar Pelangi. http://www.bbc.com/indonesia/vert_cul/2016/08/160801_vert_cul_benderapelangi.

Jeko. 2017. Indonesia Negara ke-4 dengan Pengguna Facebook Teraktif di Dunia. https://www.liputan6.com/tekno/read/2926217/indonesia-negara-ke-4-dengan-penggunafacebook-teraktif-di-dunia. Diakses pada tanggal 04 November 2018.

Pertiwi, Wahyunanda Kusuma. 2018. Riset Ungkap Pola Pemakaian Medsos Orang Indonesia. https://tekno.kompas.com/read/2018/03/01/10340027/riset-ungkap-pola-pemakaianmedsos-orang-indonesia. Diakses pada tanggal 04 November 2018.

Steve. 2018. LGBT Gay and Lesbian Whatsapp Group Invite Linke Worldwide. https://www.chapchapmarket.co.ke/lgbt-gay-and-lesbian-whatsapp-group-invite-linkworldwide/. Diakses pada tanggal 04 November 2018. 